\title{
Penelitian
}

\section{Gangguan Reproduksi Sapi Bali pada Pola Pemeliharaan Semi Intensif di Daerah Sistem Integrasi Sapi - Kelapa Sawit}

\author{
(Bali Cattle Reproductive Disorders of Semi Intensive Management in the Area of Cattle - Oil Palm \\ Integration System
}

\author{
Agung Budiyanto' ${ }^{*}$, Tarsisius Considus Tophianong'², Triguntoro³, Henny Kusuma Dewi ${ }^{4}$ \\ 'Bagian Reproduksi dan Kebidanan Fakultas Kedokteran Hewan Universitas Gadjah Mada Yogyakarta \\ ${ }^{2}$ Bagian Klinik, Reproduksi dan Patologi Fakultas Kedokteran Hewan Universitas Nusa Cendana, Kupang \\ 3Balai Veteriner Lampung \\ ${ }_{4}^{4}$ uskeswan Kampung Melayu Kotamadya Bengkulu \\ *Penulis untuk korespondensi:agung_bd2004@yaho.com \\ Diterima 16 Oktober 2015, Disetujui 12 Desember 2015
}

\begin{abstract}
ABSTRAK
Pemeliharaan sapi Bali di Kotamadya Bengkulu dengan Sistem Integrasi Sapi - Kelapa Sawit (SISKA) sudah berjalan beberapa tahun. Salah satu parameter keberhasilan program ini adalah performa reproduksi sapi Bali. Performa reproduksi sapi Bali menggambarkan kualitas dari sistem manajemen pemeliharaan yang telah dilakukan. Kajian performa reproduksi sapi Bali tersebut sudah dilakukan dengan pemeriksaan reproduksi secara per rektal dan analisa data recording peternak dan petugas. Tujuan utama dari program manajemen reproduksi adalah mendapatkan produksi yang optimal dan keuntungan yang maksimal. Efisiensi reproduksi menentukan produktivitas, profitabilitas dan keberlanjutan dari setiap usaha peternakan. Adanya gangguan reproduksi menyebabkan inefisiensi reproduksi. Kondisi ini akan menyebabkan kerugian ekonomi. Tujuan penelitian ini adalah untuk mengetahui kondisi gangguan reproduksi dan respon kesembuhannya. Sebanyak 333 ekor sapi Bali betina dengan umur minimal 2 tahun dilakukan pemeriksaan reproduksi. Metode penelitian dilakukan melalui beberapa tahap yaitu anamnesa, pemeriksaan klinis dan pemeriksaan reproduksi secara per rektal. Penanganan gangguan reproduksi dinyatakan sembuh apabila timbulnya respon klinis berupa estrus. Data yang diperoleh kemudian dicatat dan dianalisa secara deskriptif. Berdasarkan hasil pemeriksaan diketahui bahwa 193 (57,95 \%) sapi betina mengalami gangguan reproduksi yang meliputi delayed pubertas, hipofungsi ovarium, metritis, endometritis dan anestrus postpartum. Sedangkan sebanyak $80(41,45 \%)$ sapi sudah menunjukan gejala estrus. Adanya interaksi yang kompleks antara faktor lingkungan atau manajemen (nutrisi), respon individual, jenis gangguan reproduksi dan derajat keparahan gangguan reproduksi akan menimbulkan respon kesembuhan yang bervariasi dari setiap penanganan gangguan reproduksi.

Kata kunci: gangguan reproduksi, sapi bali, estrus, Bengkulu
\end{abstract}

\begin{abstract}
The maintenance of Bali cattles in Bengkulu regency with Cattle - Oil Palm Integration System (SISKA) has been running several years. The one parameters of the success this program is the reproductive performance of Bali cattle. Bali cattle reproductive performance describe the quality of the maintenance management system that has been done. Bali cattle reproductive performance study has been conducted with reproductive rectal examination and analysis of the data recording breeders and farmer. The main purpose of the reproductive management program was getting the optimal production and maximum benefit. Reproductive efficiency determines the productivity, profitability and sustainability of each farm. The inefficiency reproductive was caused by existence of reproductive disorders. These conditions cause economic losses. The purpose of this study was to determine the condition of reproductive disorders and recovery response. A total of 333 cows Bali females with at least 2 years of age has been reproductive examination. The research methods were done through clas-
\end{abstract}


sification for several stages, anamnesis, clinical examination and reproductive examination by rectally palpation. Treatment of reproductive disorders declared cured if the onset of clinical response in the form of estrus. The data obtained then were recorded and analyzed descriptively. Based on the results of the examination reported that 193 (57.95\%) of female Bali cattles experiencing reproductive disorders which include delayed puberty, ovarian hypofunction, metritis, endometritis and postpartum anestrus. While as many as 80 (41.45\%) of female Bali cattles were showing signs of estrus. The existence of complex interactions between environmental factors or management (nutrition), individual responses, the type and severity of reproductive disorders were affected of varies healing response from each treatment of reproductive disorders.

Keywords: reproductive disorders, bali cattle, oestrus, Bengkulu

\section{PENDAHULUAN}

Kebutuhan pangan asal hewan (daging) di Indonesia semakin meningkat, sementara ketersediaannya terbatas. Keterbatasan pangan asal hewan (daging) disebabkan oleh menurunnya angka kelahiran yang menyebabkan penurunan populasi ternak di Indonesia. Fakta dilapangan dan beberapa hasil kajian ilmiah telah membuktikan bahwa kondisi ini disebabkan oleh adanya penurunan performance reproduksi ternak, akibat gangguan reproduksi. Tujuan utama dari program manajemen reproduksi adalah mendapatkan produksi yang optimal dan keuntungan yang maksimal (Gitonga, 2010). Kinerja reproduksi menentukan produktivitas, profitabilitas dan keberlanjutan dari setiap usaha peternakan, dapat dikatakan bahwa tanpa reproduksi tidak akan terjadi produksi dan profitabilitas. Menurut Gitonga (2010), dikatakan bahwa jika seekor sapi tidak mengalami siklus estrus secara regular dengan calving interval 12 sampai 15 bulan, maka produktifitas, profitabilitas dan keberlanjutan usaha peternakan tidak akan tercapai.

Gangguan reproduksi secara langsung mengakibatkan kegagalan fertilisasi dan secara tidak langsung mengakibatkan estrus postpartum $>90$ hari, days open $>85-110$ hari, calving interval $>12-15$ bulan, conception rate $<60 \%$, servis per conception > 1,5 dan angka kelahiran pedet menurun. Kondisi ini akan memberi dampak kerugian ekonomi berupa adanya biaya tambahan untuk pengobatan dan perkawinan, panjangnya masa tidak produktif, meningkatnya jumlah ternak yang diafkir dan menurunnya populasi (Gitonga, 2010; Budiyanto et al., 2013).

Fakta di lapangan dan beberapa hasil penelitian membuktikan bahwa inefisiensi reproduksi sapi dapat disebabkan oleh berbagai faktor diantaranya nutrisi, penyakit, gangguan reproduksi dan manajemen pemeliharaan termasuk manajemen pemeliharaan postpartum. Nutrisi merupakan salah satu faktor penting pada kejadian gangguan reproduksi sapi potong didaerah tropis. Nutrisi dan cadangan energi tubuh dibutuhkan dalam proses metabolisme, sintesis hormon reproduksi, pertumbuhan, laktasi dan aktivitas reproduksi. Defisiensi nutrisi mengakibatkan delayed pubertas, penurunan fungsi ovarium atau hipofungsi ovarium dan dalam jangka waktu lama dapat menjadi atropi ovarium yang bersifat irreversible serta panjangnya durasi anestrus postpartum $>60-90$ hari. Selain faktor nutrisi adanya infeksi pada uterus postpartum seperti metritis puerpuralis, dan endometritis secara lansung mengakibatkan delayed involusi, dan secara tidak langsung mengakibatkan estrus postpartum > 60-90 hari, kegagalan fertilisasi dan kawin berulang atau repeat breeding, servis per conception >1,5 dan calving interval >12-15 bulan (Ahuja \& Montiel, 2005; Azawi, 2008; Gitonga, 2010).

Fakta dilapangan membuktikan bahwa $\pm 90 \%$ sapi potong pada peternakan rakyat di Bengkulu adalah bangsa sapi Bali dengan sistem pemeliharaan semi intesif "Sistem Integrasi Sapi - Kelapa Sawit" (SISKA), sedangkan sistem perkawinannya adalah perkawinan alami atau inseminasi buatan. Berdasarkan hasil pengamatan dilapangan diketahui bahwa adanya keterlambatan pubertas atau delayed pubertas pada sapi Bali yang sudah mencapai umur $>2$ tahun, adanya infeksi uterus postpartum dan anestrus yang panjang. Kondisi demikian menyebabkan inefisiensi reproduksi sapi potong di Bengkulu.

Dari uraian diatas dapat diketahui bahwa gangguan reproduksi sapi potong masih banyak terjadi pada peternakan rakyat di Kecamatan Kampung Melayu Kotamadya Bengkulu. Penanganan gangguan reproduksi dan penerapan teknologi reproduksi, seperti sinkronisasi estrus dan inseminasi buatan akan mampu meningkatkan reproduktivitas dan produktivitas sapi. Tujuan penelitian ini adalah untuk mengetahui kondisi gangguan reproduksi pada sapi Bali dan respon kesembuhannya. 


\section{BAHAN DAN METODE}

Bahan

Sebanyak 333 ekor sapi Bali betina dengan umur minimal 2 tahun dilakukan pemeriksaan reproduksi pada peternakan rakyat di Kecamatan Kampung Melayu Kotamadya Bengkulu Provinsi Bengkulu. Penelitian ini dilakukan pada tanggal 17 sampai 22 September 2015. Penentuan umur sapi pada penelitian ini berdasarkan anamnesa, estimasi gigi atau lingkar tanduk. Sistem pemeliharaan sapi Bali tersebut adalah sistem semi intesif "Sistem Integrasi Sapi Kelapa Sawit" (SISKA). Sistem ini merupakan pola pemeriharaan sapi Bali dengan cara pada waktu pagi 10.00 WIB sapi ditambat atau dilepas di perkebunan kelapa sawit dan pada sore hari 18.00 WIB sampai pagi hari sapi ditambat dalam kandang disekitar rumah pemilik. Sapi Bali tersebut memperoleh pakan berupa rumput dan daun kelapa sawit di area perkebunan. Air minum dibawakan oleh peternak atau peternak membawa sapi ke sumber air pada saat-saat tertentu di siang hari. Bahan yang digunakan adalah hormon, antara lain prostaglandin (Lutalyse), GnRH (Fertagyl), vitamin ADE, kapas, alkohol $70 \%$, albendazole, povidone iodine, aquades steril, veterinary examination glove, plastik sheat, spuit sisposable, jarum $18 \mathrm{G}$ dan tisu. Alat yang digunakan adalah insemination gun.

\section{Metode}

Pelaksanaan pemeriksaan sapi Bali dalam penelitian ini dilakukan dengan beberapa tahapan yaitu dengan metode anamnesa untuk pengisian kuisioner, pemeriksaan klinis, pemeriksaan kondisi reproduksi secara per rektal dan penanganan gangguan reproduksi. Pemeriksaan klinis meliputi body condition score (BCS), tingkah laku, leleran abnormal pada vulva dan warna mukosa vagina. Pemeriksaan kondisi reproduksi dilakukan secara per rektal terhadap cervix, corpus dan cornu uterus serta ovarium. Penentuan kondisi gangguan reproduksi berdasarkan hasil anamnesa, pemeriksaan klinis dan pemeriksaan per rektal. Penanganan gangguan reproduksi sapi Bali tersebut dilakukan kasus per kasus dari individu per individu berdasarkan pro- sedur standar yang sudah umum dilakukan. Penanganan gangguan reproduksi dinyatakan sembuh apabila timbulnya respon klinis berupa estrus. Data yang diperoleh pada pemeriksaan dan respon klinis dari penanganan gangguan reproduksi tersebut kemudian dicatat dan dianalisa secara deskriptif.

\section{HASIL}

Berdasarkan hasil penelitian yang disajikan pada Tabel 1 dapat diketahui bahwa 193 ekor mengalami gangguan reproduksi atau sebesar 57,95\% yang meliputi delayed pubertas, hipofungsi ovarium, metritis, endometritis dan anestrus postpartum. Sedangkan sebanyak 80 ekor sapi telah sembuh dengan menunjukan gejala klinis estrus atau sebesar $41,45 \%$.

\section{PEMBAHASAN}

Keterlambatan pubertas atau delayed pubertas pada seekor betina dapat dipengaruhi oleh berbagai faktor antara lain genetik, nutrisi dan faktor manajemen reproduksi. Idealnya sapi Bali mencapai pubertas pada usia 18 sampai 24 bulan dan beranak pertama kali pada usia 30 sampai 38 bulan (Talib, 2002). Di daerah tersebut tersedia rumput namun kekurangan konsentrat sehingga keseimbangan nutrisi masih rendah. Asupan nutrisi dan cadangan energi tubuh mempengaruhi aktivitas dan respon ovarium. Kurangnya asupan nutrisi akan mempengaruhi senyawa metabolisme dan hormon seperti insulin dan insulin-like growth factor-I yang mempengaruhi hipotalamus dan hipofisis terhadap respon pada ovarium dan sensitifitas gonadotropin hormon pada hipofisis sehingga energi tubuh akan menekan pelepasan gonadotropin releazing hormone $(\mathrm{GnRH})$ dan mempengaruhi frekuensi pulsatil luteinizing hormone ( $\mathrm{LH}$ ) yang diperlukan untuk pertumbuhan folikel. Kondisi ini akan menyebabkan delayed pubertas akibat folikel tidak berkembang menjadi folikel dominan atresia maupun dominan ovulasi, selain itu menyebabkan penurunan

Tabel 1 Hasil pemeriksaan gangguang reproduksi sapi Bali di Kecamatan Kampung Melayu Kotamadya Bengkulu Provinsi Bengkulu

\begin{tabular}{ccc}
\hline $\begin{array}{c}\text { Total Jumlah sapi yang diperiksa } \\
\text { (ekor) }\end{array}$ & $\begin{array}{c}\text { Jumlah kasus Gangguan Reproduksi } \\
\text { Hasil kesembuhan post treatment } \\
\text { (Estrus) }\end{array}$ \\
\hline 333 & 193 & 80 \\
\hline
\end{tabular}


fungsi ovarium atau hipofungsi ovarium yang bersifat reversible. Hipofungsi ovarium yang tidak segera ditangani akan melanjut menjadi atropi ovarium yang bersifat irreversible (Gutierrez, 2005; Gitonga, 2010).

Di daerah ini lama pedet menyusui menyebabkan kekurusan turut yang berakibat kejadian hipofungsi ovarium. Manifestasi klinis pada sapi yang mengalami hipofungsi ovarium adalah anestrus. Menyusui pedet dalam jangka waktu lama akan menunda ovulasi dan memberikan kontribusi terhadap panjang periode anestrus postpartum, sehingga efisiensi reproduksi menurun (Gitonga, 2010). Anestrus postpartum adalah periode setelah kelahiran di mana sapi tidak menunjukkan gejala atau perilaku estrus. Anestrus pada sapi postpartum adalah periode anestrus normal. Anestrus postpartum dianggap sebagai abnormal bila melampaui rata-rata 90 hari (Ahuja \& Montiel, 2005; Peter et al., 2009; Gitonga, 2010).

Anestrus postpartum yang panjang di daerah ini merupakan faktor utama yang membatasi efisiensi reproduksi pada sapi-sapi di daerah tropis, karena menyebabkan calving interval $(\mathrm{Cl})$ yang panjang yaitu >12-15 bulan. Selama anestrus, ovulasi tidak terjadi meskipun ada perkembangan folikel ovarium, namun folikel tersebut tidak tumbuh dan berkembang menjadi folikel dominan atresia maupun folikel dominan ovulasi. Menurut pendapat para ahli sebelumnya diketahui bahwa meskipun banyak faktor mempengaruhi periode anestrus postpartum, nutrisi, menyusui dalam waktu lama dan infeksi uterus postpartum adalah faktor-faktor utama yang mempengaruhi dimulainya kembali aktivitas ovarium postpartum (Ahuja \& Montiel, 2003). Mekanisme utama adalah penundaan aktivitas ovarium melalui penghambatan sekresi $\mathrm{GnRH}$ sehingga mengurangi pelepasan pulsatil dari LH yang diperlukan untuk pertumbuhan folikel (Schillo, 1992). Selain faktor nutrisi adanya infeksi pada uterus postpartum seperti metritis puerpuralis, dan endometritis secara lansung mengakibatkan panjangnya anestrus postpartum (Foldi et al., 2006; Azawi 2008; Sheldon et al., 2008). Penyuntikan vitamin ADE akan memberikan respon pada perkembangan folikel untuk mencapai ukuran folikel dominan, sedangkan penyuntikan GnRH akan memberikan respon pada perkembangan folikel mencapai ukuran ovulasi. Terapi ini akan memberikan hasil yang maksimal pada sapi yang memiliki $B C S \geq 2$.

Metritis adalah kondisi peradangan akibat infeksi pada myometrium. Metritis umumnya terjadi segera setelah partus atau pada masa puerpureum sampai hari ke-2o postpartum. Persentase kejadian metritis tertinggi yaitu pada hari ke-10 postpartum yaitu 40\%. Sedangkan kejadian endometritis klinis sering terjadi pada hari ke-15 sampai 60 atau 70 hari postpartum. Persentase kejadian endometritis klinis pada sapi adalah $20 \%$ pada hari ke-15 sampai 40 hari postpartum (Sheldon et al., 2008). Endometritis adalah kondisi peradangan pada uterus yang paling umum ditemukan. Endometritis merupakan suatu proses inflamasi yang mencakup endometrium dan merupakan salah penyebab penting dari kejadian infertilitas pada sapi (Azawi, 2008; LeBlanc, 2008)

Metritis dan endometritis di daerah ini cukup tinggi hal ini dapat disebabkan oleh kontaminasi bakteri non spesifik saat perkawinan (alami, inseminasi buatan), distokia, kebuntingan kembar, retensi plasenta, metritis puerpuralis dan penurunan atau kegagalan mekanisme aktivitas fagositosis oleh leukosit pada uterus seperti yang dikemuakakan oleh Azawi, (2008) dan LeBlanc, (2008). Karakteristik gejala klinis metritis pada sapi adalah adanya leleran cair hingga kental (viscous) berwarna merah kecoklatan sampai putih purulent keluar melalui vulva. Endometritis dapat dibedakan menjadi endometritis subklinis yang sering terjadi segera setelah partus dan tanpa menunjukan gejala klinis (Azawi, 2008; LeBlanc, 2008; Sheldon et al., 2008).

Karakteristik klinis dari endometritis klinis adalah adanya leleran purulent berwarna putih keruh kekuningan sampai mucopulent yang keluar melalui vulva dengan volume leleran bervariasi dan berbau busuk (Azawi, 2008; LeBlanc, 2008). Status nutrisi, menyusui dan infeksi uterus postpartum mempengaruhi hipotalamus dan hipofisis terhadap aktivitas ovarium. Aktivitas ovarium meliputi sintesis dan sekresi hormon steroid (estrogen dan progesterone) yang mempengaruhi pertumbuhan, perkembangan dan pematangan folikel ovarium (Burke, 2003; LeBlanc, 2008; Gitonga, 2010).

Fakta di lapangan dan beberapa penelitian telah membuktikan bahwa faktor nutrisi merupakan faktor yang lebih kritis, dalam arti baik pengaruh langsung maupun pengaruh tidak langsung terhadap fenomena reproduksi dibanding faktor lainnya. Jadi, nutrisi yang cukup dapat mendorong proses biologis untuk mencapai potensi genetiknya, mengurangi pengaruh negatif dari lingkungan yang tidak nyaman dan meminimalkan pengaruh-pengaruh dari teknik manajemen yang kurang baik. Nutrisi yang kurang baik tidak hanya akan mengurangi performans dibawah potensi genetiknya, tetapi juga memperbesar pengaruh negatif dari lingkungan. Kekurangan pakan khususnya untuk daerah tropis yang panas termasuk di Indonesia, merupakan sa- 
lah satu penyebab penurunan efisiensi reproduksi karena selalu diikuti oleh adanya gangguan reproduksi yang menyebabkan timbulnya kemajiran pada ternak betina (Budiyanto, 2012).

Pakan sebagai faktor yang menyebabkan gangguan reproduksi dan kemajiran sering bersifat majemuk, artinya kekurangan suatu zat dalam ransum pakan diikuti oleh kekurangan zat pakan yang lain (Arthur, 2001). Aktivitas ovarium postpartum dipengaruhi oleh status nutrisi dan keseimbangan energi. Status nutrisi dan cadangan energi tubuh dapat dievaluasi secara klinis melalui BCS. Perbaikan nutrisi yang meliputi kualitas dan kuantitas harus dilakukan pada sapi yang memiliki $\mathrm{BCS}<2$ sebelum terapi hormonal. Faktor genetik, lingkungan dan manajemen yang baik akan meningkatkan efisiensi reproduksi, produktivitas, profitabilitas dan keberlanjutan suatu usaha peternakan. Adanya interaksi yang kompleks antara faktor lingkungan atau manajemen (nutrisi), respon individual, jenis gangguan reproduksi dan derajat keparahan gangguan reproduksi akan menimbulkan respon kesembuhan yang bervariasi dari setiap penanganan gangguan reproduksi.

Terjadinya inefisiensi reproduksi sapi Bali pada peternakan rakyat di Kecamatan Kampung Melayu Kotamadya Bengkulu Provinsi Bengkulu akibat gangguan reproduksi. Gangguan reproduksi meliputi delayed pubertas, hipofungsi ovarium, metritis, endometritis dan anestrus postpartum. Adanya interaksi yang kompleks antara faktor lingkungan atau manajemen (nutrisi), respon individual, jenis gangguan reproduksi dan derajat keparahan gangguan reproduksi akan menimbulkan respon kesembuhan yang bervariasi dari setiap penanganan gangguan reproduksi.

"Penulis menyatakan tidak ada konflik kepentingan dengan pihak-pihak terkait dalam penelitian ini".

\section{DAFTAR PUSTAKA}

Ahuja C, Montiel F. 2005. Body condition and suckling as factors influencing the duration of postpartum anestrus in cattle: a review. Journal of Animal Science 85: 1-26.
Arthur's H, David EN, Parkinson TJ, England CW. 2001. Endogenous and exogenous control of ovarian cyclicity. In Veterinary Reproduction and Obstetrics.8th ed. Saunders.

Azawi OI. 2008. Postpartum Uterine Infection In Cattle. Animal Reproduction Science 105: 187208.

Budiyanto A. 2012. Peningkatan tingkat kebuntingan dan kelahiran sapi di Indonesia dan masalahmasalah yang terkait. seminar Updating Penyakit Gangguan Reproduksi dan Penanganannya pada Ruminansia Besar, 8 Maret 2012.

Budiyanto A, Tophianong TC, Dalimunthe NW. 2013. Perbandingan Calving Interval $(\mathrm{Cl})$ Sapi Bali Pada Peternakan Dikandangkan dan Semi Dikandangkan Di Daerah Kupang Nusa Tenggara Timur. Proceeding Seminar Nasional Peran Rumah Sakit Hewan Dalam Penanggulangan Penyakit Zoonosis. Yogyakarta, 23 November 2013.

Burke CR. 2003. Regulation of ovarian follicular development with estradiol in cattle. PhD. Disertation.The Ohio State University.

Foldi J, Kulcs'ar M, P'ecs A, Huygheb B, de Sab C, Lohuis JACM, Cox P, Huszenicza GY. 2006. Bacterial complications of postpartum uterine involution in cattle. Animal Reproduction Science 96: 265-281.

Gitonga PN. 2010. Pospartum reproductive performance of dairy cows in medium and large scale farms in Kiambu and Nakuku Districts of Kenya. Thesis. University of Nairobi Faculty of Veterinary Medicine.

Gutierrez IR. 2005. Effect of postpartum nutrition on the onset of ovarian activity in beef cows. Disertation. Oklahoma State University.

LeBlanc JS. 2008. Postpartum Uterine Disease and Dairy Herd Reproductive Performance : A Review. The Veterinary Journal 176: 102-114.

Peter AT, Vos PLAM, Ambrose DJ. 2009. Review Postpartum anestrus in dairy cattle. Theriogenology 71: 1333-1342.

Sheldon I, Erin M, Williams J, Aleisha N, Miller A, Deborah M, Nash, Shan H. 2008. Uterine diseases in cattle after parturition. The Veterinary Journal 176: 115-121.

Talib C. 2002. Sapi Bali di daerah sumber bibit dan peluang pengembangannya.Wartazoa 12: 3 . 